$\underline{\text { P R Z E G L A D Y }- \text { O M Ó W I E N I A }- \text { R E C E N Z J E }}$

ROCZNIKI HUMANISTYCZNE

Tom LXIX, zeszyt $1-2021$

DOI: https://doi.org/10.18290/rh21691-10

WOJCIECH KUDYBA

\title{
ZNANY, NIEZNANY HAUPT
}

Jeszcze pod koniec ubiegłego wieku wspólnoty interpretacyjne literaturoznawców traktowały listy i bruliony wyłącznie jako materiał pomocniczy w badaniach nad twórczością kanonicznych autorów. Do pojęcia kanonu odwołuję się świadomie. Na edycję mogły wówczas liczyć jedynie bloki epistolograficzne oraz notatki kilku najbardziej dostojnych klasyków literatury narodowej - poza zasięgiem druku pozostawali więc zarówno ich respondenci, jak i pisarze spoza głównych rozdziałów historii literatury polskiej. Wszystko zmieniło się u progu trzeciego tysiąclecia. Lata 1989-2019 można nazwać „trzydziestoleciem intymistyki”, bowiem listy, notatki, wspomnienia i dzienniki stały się w tym czasie ważną częścią rynku wydawniczego, uzyskując również status pełnowartościowego materiału dociekań naukowych. Obszar prac badawczych poświęconych pismom intymistycznym, nieustannie zresztą rozszerza się i różnicuje - także pod względem naukowej wartości rozmaitych propozycji. Piszę o tym wszystkim, ponieważ badania Pawła Panasa, zwieńczone dysertacją ,"Zagubiony wpośród obcych”. Zygmunt Haupt-pisarz, wygnaniec, outsider (Panas), stanowią w ramach wspomnianego obszaru propozycję ważną i ciekawą.

Autor pochylił się nad twórczością prozaika, który cieszy się ostatnio uznaniem literaturoznawców, wciąż jednak pozostaje na obrzeżach świadomości literackiej szerszego kręgu czytelników. Choć pismom literackim Zygmunta Haupta poświęcali swe monografie Andrzej Niewiadomski (Niewiadomski) i Aleksander Madyda (Madyda) (na ostatnich stronach rozprawy odnajdziemy rzetelną bibliografię prac hauptologicznych), to trudno nie zauważyć, że wyniki

Prof. dr hab. WOJCIECH KUDYBA - kierownik Katedry Literatury XX wieku, Instytut Filologii Polskiej w Uniwersytecie Kardynała Stefana Wyszyńskiego; adres do korespondencji: ul. Dewajtis 5, 01-815 Warszawa; e-mail: w.kudyba@uksw.edu.pl; ORCID: http://orcid.org/0000-0001-5868-3850. 
ich badań są znane jedynie wąskiemu gronu badaczy. Wydaje się, że włączenie w krwiobieg polskiej literatury twórczości pisarzy, pozostających w latach PRL na emigracji, wciąż jest ważnym zadaniem wszystkich uczestników współczesnej kultury literackiej. Choć mogło być inaczej, realia są bezlitosne: w ostatnich dziesięcioleciach w dzieło przywracania emigracyjnych autorów polskiej świadomości literackiej zaangażował się niewielki krąg badaczy - głównie starszego pokolenia. Trudno nie docenić faktu, że właśnie dołączył do tej grupy młody literaturoznawca - obdarzony pasją i talentem, które mają szanse owocować przez długi czas. Klarowna, napisana z polotem i stylistyczną elegancją, wyposażona przy tym $\mathrm{w}$ interesujący materiał ilustracyjny (odnajdziemy tu zarówno zdjęcia miejsc, w których pisarz przebywał, jak i fotografie autografów jego tekstów) omawiana książka może pełnić ważną rolę w popularyzacji wiedzy o Haupcie. Nie zmienia to faktu, że o jej wadze decydują walory stricte naukowe.

Przedmiotem naukowych dociekań Pawła Panasa stały się bowiem teksty dotąd nieznane - wydobyte dzięki żmudnym i czasochłonnym kwerendom w archiwach krajowych i zagranicznych, o czym autor informuje $z$ właściwą sobie powściągliwością:

W trakcie prac nad książką udało się między innymi dotrzeć do trzech najważniejszych zbiorów Hauptowskiej korespondencji z Józefem Wittlinem (archiwum zdeponowane w bibliotece Uniwersytetu Harvarda), z Jerzym Giedroyciem i pozostałymi członkami zespołu redagującego „Kulturę” paryską (archiwum zdeponowane w Instytucie Literackim w Maisons-Laffitte) oraz Aleksandrem Jantą-Połczyńskim (archiwum Biblioteki Narodowej w Warszawie). Udało się także przeprowadzić osobne badania nad najważniejszą kolekcją, archiwum pisarza przechowywanym w Bibliotece Uniwersytetu Stanforda. (Panas 17)

Dobrze się stało, że ważny fragment tego trudno dostępnego korpusu tekstów tj. korespondencja z Jerzym Giedroyciem - został zamieszczony w książce (por. 129-150). Badacz słusznie zakłada, że odkryty i opisany przezeń obszar tekstowy pozostaje otwarty na dalsze literaturoznawcze eksploracje. Co więcej: wielokrotnie świadomie zgłasza na kartach książki różnego rodzaju propozycje badawcze z nadzieją, że zostaną one podjęte przez nowych czytelników prozy Haupta.

Metodologiczna wartość prac podjętych przez lubelskiego badacza polega zatem m.in. na tym, że (nawiązując do prac innych polonistów z kręgu KUL oraz UKSW) inicjują one konsekwentny - i kompetentny! - literaturoznawczy zwrot $\mathrm{w}$ stronę tekstu. Umiejętnie łączą dobre tradycje filologiczne $\mathrm{z}$ osiągnięciami najnowszego edytorstwa tekstologicznego. Dowodzą, jak ważne są 
tego typu badania w ustalaniu i uwiarygodnianiu historycznoliterackiej narracji o pisarzach, nurtach, a nawet - o epokach literackich. Pamiętamy Romantyzm ,brulionowy” Ewy Szczeglackiej-Pawłowskiej (Szczeglacka-Pawłowska), który odnowił nasze spojrzenie na utrwalony w podręcznikach historii literatury wizerunek całej epoki literackiej. Z podobnych powodów zapamiętamy książkę Panasa, która - dzięki wnikliwej lekturze notatek pisarza - każe uzupełnić zakorzeniony $\mathrm{w}$ literaturze przedmiotu wizerunek artysty o zupełnie nowe elementy. Jeśli niewiele do tej pory wiedzieliśmy np. o dojrzewaniu pisarza, to warto zapoznać się choćby z passusem, którego puenta brzmi następująco:

Przedwojenny dorobek Haupta jest dosyć skromny i w zasadzie nie ma on większego znaczenia z punktu widzenia historycznoliterackiego, jest natomiast ciekawym dokumentem do badania pisarskiej ewolucji przyszłego autora Pierścienia z papieru. Daje również wgląd w formowanie się jego twórczej samoświadomości [...]. (187)

Ostatni rozdział książki, zatytułowany „Balon”. Rekonesans $w$ archiwum pisa$r z a$ można potraktować właśnie jako egzemplifikację pożytków płynących z lektury pism skrywanych przez artystę - a więc nieoficjalnych i szkicowych. Chodzi o bruliony Haupta zdeponowane w Bibliotece Uniwersytetu Stanforda, które badacz poddał drobiazgowemu, niekiedy iście detektywistycznemu śledztwu tekstologicznemu. Wyniki tych zabiegów okazały się niezwykle interesujące. Panas odsłonił zupełnie nowy, zaskakujący obraz preferowanych przez Haupta metod pracy pisarskiej, a tym samym skłonił do poszerzenia naszej wiedzy o osobowości twórczej autora Pierścienia z papieru. Jak czytamy, lektura brulionów prozaika:

[...] ujawnia pisarza jako swoistego montażystę, operującego fragmentami tekstów niczym gotowymi lub półgotowymi elementami. Obserwowanie ich dekontekstualizacji oraz ponownej kontekstualizacji pozwala wzmocnić, lub też osłabić, niektóre z dotychczasowych kwalifikacji interpretacyjnych. (228)

Okazuje się, że archiwum stanfordzkie mieści w sobie m.in. kilka brulionów zatytułowanych Balon, żaden z nich nie zawiera jednak elementów opowiadania, które - tak właśnie zatytułowane - ukazało się na łamach Kultury. Znawca prozy Haupta nie bez zaskoczenia musi zauważyć, że: „Zdecydowaną większość z tych materiałów możemy dosyć łatwo zidentyfikować jako kolejne wersje innego, bardzo znanego opowiadania Haupta, noszącego tytuł Baskijski diabel" (225). Lubelski tekstolog dodaje, że istnieje również taka brulionowa wersja Balonu, która nie ma nic wspólnego nie tylko z tak zatytułowaną miniaturą prozatorską, ale również ze wspomnianym Baskijskim diabłem. Jedynie 
pasja i dociekliwość badacza sprawiły, iż zobaczyliśmy, jak ów brulion uległ osobliwej dekompozycji i - w postaci drobnych elementów - został rozsiany na całkiem sporym obszarze eseistyki pisarza.

W innym miejscu książki natrafiamy na opis głównych wątków korespondencji Haupta z redaktorami czasopism literackich, w których on publikował swe teksty. Kwerendy Panasa pozwoliły m.in. na wyjaśnienie opóźnionego debiutu Haupta na łamach paryskiej Kultury. Jak czytamy, decydującą rolę odegrała ocena wystawiona przez Gustawa Herlinga-Grudzińskiego:

Ten, poproszony przez Giedroycia o zaopiniowanie nadesłanych do redakcji tekstów, w części poświęconej Hauptowi napisał: „,...] niezła imitacja Brunona Schulza, ale nie warto drukować w «Kulturze»”. (92)

Badacz pokazuje również różnego rodzaju inspiracje, otrzymywane przez Haupta ze strony środowiska Kultury, które ostatecznie szeroko otwarło mu swe podwoje. Ciekawie opisuje osobliwy dialog epistolarny, prowadzony przez pisarza z Jerzym Giedroyciem, jako przestrzeń spotkania osób, które zmieniają się dzięki wzajemnej interakcji. Autor opracowania pokazuje zarówno rosnącą otwartość i bezinteresowność redaktora, jak i dojrzewania pisarza, który nie pozwala odebrać sobie wypracowanego literackiego idiomu, nasycając nim wszystkie obszary swej aktywności - także tej recenzenckiej i translatorskiej, wiedząc o nieporozumieniach i sprzeciwach, jakie podobny upór może wywoływać.

Nie mniej interesujący - z punktu widzenia tekstologii - wydaje się etap współpracy Haupta z Wiadomościami. Ważną część zmagań debiutującego pisarza $\mathrm{z}$ ich naczelnym redaktorem odsłonił kiedyś Aleksander Madyda, który - nie kwestionując zasług Mieczysława Grydzewskiego w promocji prozy mało znanego autora (w latach 1947-1950 na łamach Wiadomości ukazało się 19 utworów Haupta) - pokazał, jak głęboko sięgały ingerencje redaktora w literacką tkankę utworów pisarza. Uzupełniając i ukonkretniając ów obraz, lubelski badacz cytuje m.in. następujące uwagi redaktora: ,jeśli wolno radzić, na miejscu Pana porzuciłbym sposób chaotycznego pisania okresów, czasem nawet bez orzeczenia. Myślę, że ten sposób jest na długo męczący. Prosta proza nigdy się nie nudzi. Mnie samemu bardzo się to podobało na początku, ale jest to efekt jednodniowy" (100). Jak przekonuje autor rozprawy, pisarz traktował podobne uwagi niezwykle poważnie, a czynił to właśnie wtedy, gdy kształtował swój pisarski idiom. Czy można więc mówić o wpływie Grydzewskiego 
na warsztat pisarski Haupta? Odpowiedź autora książki na to pytanie brzmi następująco:

Żeby móc precyzyjniej ocenić w tym przypadku rodzaj i skalę oddziaływania na pisarza, potrzebne byłyby dalsze, pogłębione analizy tekstologiczne porównujące pierwodruki oraz materiały w archiwum Haupta, wszystko to zaś w ujęciu diachronicznym. (102)

Odkrycia Panasa prowadzą zatem do istotnej zmiany paradygmatu działań edytorskich w obszarze twórczości prozaika. Badacz słusznie podkreśla, że

uważna analiza zawartości archiwum Haupta, w szczególności zachowanych szkiców i brulionów jego twórczości prozatorskiej, nadal wydaje się koniecznym warunkiem przyszłej edycji dzieł autora Pierścienia z papieru (128).

Skłonność pisarza do ulegania różnego rodzaju sugestiom redaktorów i do redystrybucji fragmentów własnych tekstów ma też ogromne znaczenie dla budowania hipotez interpretacyjnych, tyczących trudniejszych utworów.

Okazuje się bowiem, że niektóre fragmenty sprawiające kłopoty natury interpretacyjnej są zdekontekstualizowanymi urywkami innych całości. Wobec tego analiza retrospektywna w połączeniu $\mathrm{z}$ innymi, typowo literaturoznawczymi metodami daje szansę na lepsze zrozumienie (tamże).

Monografia Pawła Panasa w istotny sposób podwyższa standardy naukowego poznawania utworów Haupta. Sprawia, że nie będziemy mogli już ich czytać tak, jak do tej pory.

Źródłem metodologicznej świeżości prac lubelskiego literaturoznawcy nie jest jednak wyłącznie rozwój nowoczesnej tekstologii. Autor „Zagubionego wpośród obcych" Zygmunt Haupt korzysta również z owoców zwrotu antropologicznego, jaki dokonał się w badaniach literackich. Przedmiotem jego uwagi nie są wyłącznie tekst i twórca (rozumiany jako rodzaj antropomimetycznej maszyny do pisania). Wspomnianemu zwrotowi zawdzięczamy wszak ważne przypomnienie, że autor - także wtedy, gdy wchodzi w rolę pisarza - nie przestaje być człowiekiem. A jeśli tak, to istotnym kontekstem interpretacyjnym jego twórczości muszą być doświadczenia egzystencjalne, tworzące osnowę jego pojedynczego, unikalnego, ludzkiego losu. Trudno też zaprzeczyć, że w pismach intymistycznych ów kontekst biograficzny jest fundamentem procesu rozumienia tekstowego komunikatu. To dzięki niemu jesteśmy w stanie rozpoznać podstawowe dane antropologiczne wpisane już to w listy, już to w notatki pisarza. 
Ich lektura staje się więc ostatecznie refleksją nad podmiotem, jaki ujawnia się w korpusie intymistycznych tekstów artysty. Tak właśnie dzieje się w omawianej dysertacji. Wygnanie staje się podstawową (antropologiczną!) kategorią badawczą, sama analiza epistolografii, oparta na fundamencie tekstologicznym, zmierza zaś do ukazania rozmaitych aspektów wpisanej w listy Haupta figury pisarza-emigranta.

Wypada więc przypomnieć, że listy autora Baskijskiego diabła nie cieszyły się dotąd przesadnym zainteresowaniem historyków literatury. Poświęcono im ledwie kilka artykułów, upowszechniając przekonanie, którego ślad lubelski badacz wytropił w pracach Andrzeja Niewiadomskiego: „miłośnicy tej twórczości nie mogliby się spodziewać po ich [listów] liczbie i lekturze istotnej zmiany warunków postrzegania pracy autora" (25). Dokonane przez Pawła Panasa eksploracje w archiwach, o których mówiliśmy, w radykalny sposób podważają wiarygodność podobnych sądów. Dostarczają trudnych do zakwestionowania dowodów na to, że w rzeczywistości sytuacja przedstawia się zgoła odwrotnie - zarówno liczba, jak i zawartość listów Haupta mogą mieć istotny wpływ na zmianę naszego wyobrażenia o pracy pisarza i jej warunkach. Mówi o nich tytuł rozprawy. Książka „Zagubiony wpośród obcych”. Zygmunt Haupt - pisarz, wygnaniec, outsider, jak żadne inne opracowanie poświęcone pisarzowi wielostronnie omawia wygnańczą kondycję podmiotu jego twórczości, znacznie wzbogacając stan naszej wiedzy o niej. Osią kompozycji opracowania pozostaje porządek tekstologii, jednak analizy omawianych sukcesywnie archiwaliów konsekwentnie zmierzają właśnie w stronę ukazania wygnańczej kondycji ich autora. Trudno tu mówić o wyraźnej chronologii - zakresy czasowe poszczególnych zbiorów tekstów zachodzą na siebie - stąd czytelnik próbujący uchwycić diachronię emigracyjnych doświadczeń pisarza może odczuwać pewien dyskomfort. Jeśli jednak nie brak mu stosownej determinacji i zmysłu intelektualnej przygody, poszukiwanie stosownych informacji, rozproszonych w rozmaitych rozdziałach opracowania, może mu dostarczyć specyficznej satysfakcji.

Wędrując w poprzek kompozycyjnej osi książki, poznajemy zatem m.in. wczesne stadium emigranckiego losu artysty. Analizując listy Haupta i zestawiając je z innymi źródłami wiedzy o jego biografii, Panas w kolejnych rozdziałach rozprawy - od pierwszego począwszy - odsłania pasjonujące i w jakiejś mierze pasyjne, bolesne zmagania pisarza z problemem izolacji i osamotnienia w zupełnie obcym środowisku kulturowym i językowym - najpierw w Nowym Jorku, a następnie w Nowym Orleanie. Dowiadujemy się o powściągliwości artysty w ujawnianiu osobistych stanów emocjonalnych i jego niechęć do ja- 
kichkolwiek artykulacji skargi (która dość rzadko pojawia się w jego korespondencji). Czytamy jednak również o narastającej, niemal obsesyjnej potrzebie osobistych spotkań z rodakami i heroicznych wysiłkach w poszukiwaniu kontaktów z polskimi literatami oraz żywym polskim językiem. Poznajemy bohaterską, choć przegraną walkę ojca o możliwość porozumiewania się z własnym dzieckiem w języku polskim. Nade wszystko jednak obserwujemy nietypową metamorfozę epistolograficznej narracji, która w podobnych sytuacjach granicznych zwykle doprowadza do ekspozycji obolałego ,ja”. U Haupta jak przekonująco dowodzi badacz - ma miejsce proces odwrotny: stopniowe ograniczanie żywiołu zwierzeń osobistych na rzecz refleksji o charakterze ponadjednostkowym, mocno zuniwersalizowanym. Tłem zjawiska jest oczywiście ważna, wewnętrzna praca pisarza nad oswojeniem nowej przestrzeni kulturowej, a tym samym nad reinterpretacją samego doświadczenia wygnania. W listach emigranta badacz odnajduje ślady ponawianych przez prozaika prób nowego określenia własnej sytuacji egzystencjalnej oraz wyraźną linię przemian świadomościowych, który doprowadza podmiot Hauptowskiej epistolografii do istotnej redefinicji samego siebie. O ile bowiem we wczesnych listach zapisuje on ból kogoś pozbawionego swego własnego miejsca na ziemi, o tyle już w latach pięćdziesiątych identyfikuje się nie tyle z rolą wygnańca, ile raczej z rolą outsidera, krytycznego obserwatora - zdystansowanego zarówno wobec Ameryki, jak i Polski.

Jak przekonuje badacz, pisarska droga Zygmunta Haupta zatacza koło - wiedzie z kraju do Ameryki i z powrotem. Ów powrót dokonuje się jednak nie dzięki pracy służb transportowych, lecz dzięki pracy pamięci. Jest powrotem mentalnym, jego świadectwem nie jest jakikolwiek dokument realnej podróży, lecz tekst literacki. Jeśli w latach 1946-1947 Haupt zapisywał w swych listach ból utraty świata, którego czuł się częścią, jeśli towarzyszyła mu gorycz wydziedziczenia i w jakimś sensie wyzucia z polskości, to epistolografia z lat późniejszych jest zdaniem badacza przejmującym świadectwem wysiłku scalania rozsypanej tożsamości oraz integrowania własnej osobowości pisarskiej. Osią owej integracji nie jest jednak i nie może być przestrzenne „teraz” - zawłaszczone i zniszczone przez Sowietów - lecz temporalne „dawniej”. Dla Haupta:

Pisać to tyle, co odrywać się od swoich czasów i środowiska, przekraczać aktualność rozpoznanych konwencji, odkrywać dotąd nieodkryte oraz opisywać do dzisiaj nieopisane. (176) 
Pisarz, wygnany z kresów drugiej Rzeczpospolitej, powraca do nich mentalnie. Fizycznie mieszka w Ameryce, ale pamięcią mieszka tam, gdzie się urodził i gdzie spędził młodość. Wygnanie staje się dla niego „szansą na powrót, banicja - okazją do ponownego zadomowienia" (177). Geograficzno-kulturowa bariera nie przerywa jego związku z „krajem lat dziecinnych”, skutkuje jedynie swego rodzaju dystansem - niezwykle owocnym artystycznie. Ów dystans - jak pokazuje Panas - chroni bowiem autora Pierścienia z papieru zarówno przed ciśnieniem bieżącej aktualności, jak i presją pamięci - koloryzującej wspomnienia. Pisarz wzbrania się przed taką rekonstrukcją świata po zagładzie, której motywacją jest nostalgia, dzielnie broni się przed pokusą mitologizacji polskich Kresów, przezwyciężając konwencje, jakie wytwarzała powstająca wówczas $\mathrm{w}$ wielkiej obfitości literatura wspomnieniowa. Jak pokazuje badacz, Haupt stopniowo zaczyna sobie zdawać sprawę, że:

Tylko outsider jest w stanie tworzyć wbrew temu, co uchodzi za powszechnie akceptowane i jednocześnie nieskończenie wiele razy w różnych wariantach później powielane. (185)

Ważne spostrzeżenia Panasa dotyczą także specyfiki podejmowanej przez pisarza pracy pamięci, która wydobywa z przeszłości nie tylko obrazy i zdarzenia, ale także brzmienia słów:

Proza Haupta nasycona jest brzmieniami rodzimej słowiańszczyzny [...] fonetyczna warstwa języka przywoła również jego semantyczne dziedzictwo. Słowa w twórczości autora Pierścienia z papieru stwarzają nowe światy, ale jednocześnie przywołują nieistniejące już, o których chciałoby się wciąż pamiętać [...]. (205)

Szczególnie wyraźnym dokumentem ewolucji wygnańczej świadomości pisarza jest nieznana dotąd korespondencja pomiędzy Zygmuntem Hauptem i Józefem Wittlinem - opisana przez lubelskiego tekstologa $\mathrm{z}$ wielką starannością w osobnym podrozdziale. Umieszczony w jego tytule cytat $\mathrm{z}$ listu młodszego pisarza do starszego - „Pan jest starym emigrantem” - zdaje się określać formę i ramy wypowiedzi obu korespondentów. Jak czytamy, Wittlin rzeczywiście starszy i doświadczeniem życiowym, i doświadczeniem wygnańczym - od początku funkcjonuje we wspomnianym bloku tekstów jako mentor. Służy emigranckiemu debiutantowi radami w najprzeróżniejszych sprawach. Rozwiewa rozmaite ułudy, pomaga przezwyciężyć bolesne rozterki, nade wszystko zaś buduje przestrzeń dialogów o literaturze - obszar, który dla Haupta staje się swego rodzaju alternatywnym światem, pozwalającym na 
wytchnienie od trudów i ran nieuchronnie związanych z zanurzeniem w realności amerykańskiej prowincji. Autor Soli ziemi - Panas mocno to podkreśla - stwarza zatem sieć informacji o konkretnych dziełach literackich (np. Henry'ego Jamesa) a także o literaturze jako takiej - o jej powinnościach i możliwościach. Jak zauważa badacz, oczka owej sieci stają się niekiedy ważną inspiracją dla pisarza tworzącego dopiero swój warsztat i swój paradygmat myślenia o tym, czym jest sztuka literacka i jakie ma zadania.

Dysertacja „Zagubiony wpośród obcych”. Zygmunt Haupt-pisarz, wygnaniec, outsider pozwala zatem obserwować rodzenie się i rozwój warsztatu pisarskiego Haupta w przestrzeni dialogu. Jego listy i notatki - opatrzone przez badacza erudycyjnymi odsyłaczami i przypisami - od początku oglądamy jako wycinek ukrytej, mocno splątanej grzybni interpersonalnych oraz intertekstualnych powiązań, z których $\mathrm{w}$ tajemny sposób wyrosną z czasem owocniki wyjątkowych dzieł pisarza. A także malarza. Panas wspomina o tym na tyle często, że czytelnik-polonista zaczyna mieć żal do historyków sztuki, iż nie podjęli dotąd trudu opisu i popularyzacji wizualnych dzieł Zygmunta Haupta. Ja każda udana monografia, również ta wyznacza różnego rodzaju zadania przyszłym badaczom tekstów pisarza. Wypada mieć nadzieję, że pojawią się wśród nich także tacy, którzy - łącząc kompetencje znawców sztuki i literatury - będą potrafili nie tylko oddać sprawiedliwość malarskim dokonaniom Haupta, ale także staną się zdolni do wyśledzenia i opisu podziemnych przejść łączących plastyczne i literackie dzieła artysty, ukażą skryte przecieki pomiędzy jego opowiadaniami i obrazami. Wciąż zbyt mało wiemy o Haupcie malarzu, a jeszcze mniej o Haupcie sztuk-mistrzu, alchemiku mieszającym w swej artystycznej retorcie kody wizualne i werbalne. Oby się to zmieniło.

\section{BIBLIOGRAFIA}

Madyda, Aleksander. Haupt. Monografia. Wydawnictwo Naukowe UMK, 2012.

Niewiadomski, Andrzej. Jeden jest zawsze ostrzem. Inna rzeczywistość Zygmunta Haupta. Wydawnictwo UMCS, 2015.

Panas, Paweł. „Zagubiony wpośród obcych”. Zygmunt Haupt - pisarz, wygnaniec, outsider, Biblioteka Pana Cogito. Wydawnictwo Naukowe ATH, Instytut Literacki, 2019.

Szczeglacka-Pawłowska, Ewa. Romantyzm „, brulionowy”. Wydawnictwo UKSW, 2015. 